\title{
Research on College Talent Training Mode Based on Collaborative Innovation of Production, Studying and Research
}

\author{
Liu Rujing \\ Changchun Institute of Architecture, Changchun, 130607, China \\ 45138913@qq.com
}

Keywords: Integration of production, Study and research, Talent training mode, Applied talents

\begin{abstract}
With the development of national society, knowledge has become the key factor of international competition. The demand for innovative and applied talents in our country has been constantly expanding. Under such circumstances, this article starts with the collaborative innovation mechanism of production, education and research, and deeply studies the talent training mode in colleges and universities in the new era. After a comprehensive understanding of the collaborative innovation of college talent training mode in production, studying and research, it briefly describes the existing problems and puts forward some suggestions on how to develop talent training in order to provide applied talents for our country.
\end{abstract}

\section{Introduction}

In recent years, the reform of the state education system has been deepening constantly and the reform of colleges and universities is also developing continuously. A brand new talent cultivation mode - "Production, Studying and Research" has been put forward. This model of education is in line with the actual conditions in colleges and universities, combining theory with practice in an all-round way, and it can cultivate professional talents who meet the needs of society. Use of this new training mode of production, study and research to improve students' application skills and innovative ability, It is of great practical significance to take advantage of this brand new training mode of production, study and research to improve students' applied skills and innovative abilities, maximize the innovative application of innovative subjects and improve the competitiveness of colleges and universities.

\section{The contents of College Talent Training mode on Collaborative Innovation of Production, Studying and Research}

National talent cultivation can be divided into two major categories, academic and professional, respectively. With the development of the times, the mode of cultivating talents through cooperation among production, studying and research institutes has gradually received the attention of colleges and universities. The advantages of this collaborative model of talent training are becoming gradually obvious. At the same time, with diversified modes, the content of teaching is increasingly enriched, changing the disconnect between talent education and social practice. Based on the talent training mode of production, study and research, colleges and universities should also help students to accumulate rich practical experience in the field of theoretical knowledge teaching, as well as joint ventures and related research bases and research and development centers to form training mechanisms and joint training of personnel on key projects. Although the education of production, studying and research started relatively late in our country, it developed rapidly. Since the establishment of the first cooperation base of production, studying and research in 1919, the education of production, studying and research in our country has been developing continuously. Among them, the education mode proposed by Beijing University of Technology has has a certain representation. Based on this cooperative education mode of production, studying and research, 
universities and enterprises unite with students as linkages, and finally realize the education mode with enterprises as the carrier of cooperation. However, at this stage, there is still a certain gap between the mode of collaborative innovation and education in production, studying and research in the country and the advanced countries in the west. The national mechanism for collaborative innovation and education of production, studying and research needs to be further developed. We must continue to strengthen research and production Mechanism to explore more ways of educating people, in line with the characteristics of the national education system reform and the development of the times. The combination of production, studying and research is an important way to promote innovation and entrepreneurship of college students. Therefore, it is necessary to comprehensively promote the synergy of production, study and research Innovative educational mechanism [1].

\section{The problems of College Talent Training mode on Collaborative Innovation of Production, Studying and Research}

It can be seen from the above that it is still at a very early stage for the state to develop a co-innovative training model for production, studying and research, and still in its infancy. In the process of practice, it is still at a certain stage of problems.

\subsection{Paying less attention to the cultivation of innovative modes of production, studying and research}

With increasing of the number of colleges and universities, although the number of students who apply for entrance examinations is also constantly improving, the average number of applicants from different colleges and universities has been calculated and it is found that there are fewer and fewer applicants in some colleges and universities. Therefore, although the competition among colleges and universities is getting fiercer, while the quality of colleges and universities is an inevitable prerequisite for the survival and development of colleges and universities. Therefore, many colleges and universities will declare scientific research projects, award levels and other aspects as one of the teacher assessment criteria, in this way, to enhance the overall professional quality of teaching staff, and fundamentally improve the practical ability and creative ability of students. However, there are still some teachers in colleges and universities not paying enough attention to the talent training mechanism of collaborative innovation in production, studying and research. They think it is not necessary to use them in the classroom. Therefore, they still follow the traditional model of talent training.

\subsection{The traditional college personnel training mode is relatively backward}

From the above we can see that at this stage the traditional training model of colleges and universities is lagging behind, most of them adopt oral teaching in the form of teaching, while the assessment system also takes exams as the main assessment methods. Part of the examination reform is a mere formality and has not shown the true effect of the reform. Under such circumstances, the talent training mode has not been really developed. The talents trained are lack of characteristics and not conducive to talent innovative development.

\subsection{The university's teacher team also needs to be fully upgraded}

Not only the problem of teaching mode, with the development of production, teaching and research training mechanism in colleges and universities, the problems existing in the team of teachers are gradually exposed. Especially for non-government colleges and universities, they are affected by many factors, lack of professional teachers and even a small number of private Colleges and universities allow teachers with similar professions to conduct multi-disciplinary teaching. Under the condition of a severe shortage of teachers and a mixed class of teachers, the professional theoretical knowledge can not be well communicated, which has a serious impact on the development of talent training modes for collaborative innovation in production, studying and research [2].

\subsection{College students lack of subjective enthusiasm, poor ability}


In addition to the above three points, there are still some subjective problems in carrying out talent training problems of collaborative innovation of production, studying and research. Many students are opposed to the innovative teaching methods of teachers. They think that teachers have more tasks and complicated contents, lack of enthusiasm and subjective initiative, which directly lead some students not to devote themselves to completing their tasks. The role of production, studying and research can not be truly played. Students' ability to innovate has not really improved, nor has their imagination and thinking ability greatly improved. There will be no great progress, and the cultivation of innovative talents in production, studying and research will gradually flow to the formality.

\section{Strategies to College Talent Training mode on Collaborative Innovation of Production, Studying and Research}

\subsection{Based on External Construction of College Talent Training mode on Collaborative Innovation of Production, Studying and Research}

\subsubsection{Establish a university-enterprise and business-oriented integration of production, studying and research}

Collaborative innovation refers to the establishment of an organic whole of research, learning, innovation and application integration. As a brand new mode of personnel training, enterprises are the most crucial link in the cooperation between production and studying. Schools provide talents for enterprises and enterprises training students practical ability and practical ability, therefore if you want to establish a good cooperative training model for production, learning and research,, it is necessary to establish the formation of colleges and universities and enterprises as the mainstay of the integration of research and development, industry development as its point, concerned about the future direction of the industry and industry needs, actively developing new engineering projects and enterprises, and the scientific and technological achievements directly into the enterprise, so that talent training to meet the new era of enterprise demand for suitable production. For example, Beijing Han Long Technology Co., Ltd. developed a new product, and five domestic colleges and universities to carry out cooperation in production, studying and research, achieved good results. Under the personnel-training mechanism of production, study and research, the significance of school-enterprise cooperation and job internship has been obviously changed. Schools and enterprises all take the cultivation of applied talents as the starting point to enhance students' practical ability and application ability. Therefore, colleges and universities in the training of outstanding personnel in the process, can not blindly develop personnel training programs, and should have comprehensive consideration from students, society, businesses, etc.

\subsubsection{To form a talent market as the mainstay of production output}

Enterprises and markets are the ultimate port of delivery after the training of university personnel. The market and the demand of enterprises determine the direction and development opportunities for university students. Therefore, under the model of training innovative talents in production, learning and research, in addition to establishing an integration of production, studying and research with colleges and enterprises as the mainstay, a talent market-led talent output direction has to be formed [3]. Mentioned above, colleges and universities in the formulation of talent training mode, we must consider the development of the industry, in addition, colleges and universities and enterprises in the process of cooperation, but also give full consideration to market demand, market demand as the direction of personnel training to construction colleges. For example, Taking construction colleges as an example, in the process of talent cultivation, we can regard the concrete application of engineering practice as the main way to cultivate talents. 


\subsubsection{To form a research platform for the carrier of the transformation of production and research}

Students in the process of learning basic theory, but also pay attention to the application of scientific research, and then lay the foundation for future scientific research work, colleges and universities should make full use of the internal resources of cooperative enterprises to build a research and development platform to train students to innovate. Through the research platform and practice place co-founded by colleges and enterprises, the real integration of industry, education and research will be implemented and the talent will be delivered to the market and users. In this process, colleges and universities assume the main task of theoretical teaching, and enterprises undertake practical training tasks. In addition, in the process, colleges and universities should also actively collect feedback from the market and enterprises, adjust and optimize the training programs, ensure the role of industry, education and research cooperation in educating people has been fully exploited, providing compound talents in line with the needs of society and realizing the in-depth integration of colleges and enterprises.

\subsubsection{Improve laws and regulations based on collaborative innovation of production, studying and research}

The system can constrain the behavior and guarantee the rights. However, Collaborative innovation of production, study and research, the system of cooperation projects of production, involves many fields, including universities, markets and enterprises. The relationship between the three is complex and changeable and can not rely on the self-regulating ability of any one of them to achieve normal operation Therefore, if we want to ensure the cultivation of applied talents, it is necessary for relevant departments to comprehensively integrate the interests of all parties, improve the laws and regulations on collaborative innovation of production, learning and research, and from the source to strengthen the training of application-oriented personnel in the process of supervision, management and security [4]. For example, the government can determine the social status of innovative and applied talents in the form of laws by providing relevant legal provisions to provide guarantee for personnel training. On this basis, the government can play a supervisory role in enterprises, markets and colleges and ensure that enterprises can play a fundamental role in personnel training, schools can also be more proactive to establish the appropriate teaching evaluation system, according to the relevant laws and regulations to improve the teaching management system.

\subsection{Based on Internal Construction of College Talent Training mode on Collaborative Innovation of Production, Studying and Research}

\subsubsection{Strengthen the cultivation of young teachers}

The teaching team is the foundation for carrying out talent training work in colleges and universities. Teachers' classroom teaching characteristics, teaching ability and teaching means all have an impact on the classroom teaching effect, which hinders the development of collaborative innovation in production, studying and research. Therefore, improving teachers 'professional quality and skill level can effectively improve teachers' teaching quality and ultimately realize the maximization of college teaching effectiveness. At this stage, young teachers in colleges and universities are the backbone of teaching staff in colleges and universities. Therefore, colleges and universities want to improve the quality of teaching from the young teachers, and then spread to the whole school. First, university teachers can arrange for young teachers to conduct collective lesson preparation. Second, they should establish contacts with other teaching institutions to form inter-disciplinary interactions. Third, young teachers should be encouraged to pursue their own studies and actively participate in academic exchange activities both at home and abroad. Through these three aspects, young teachers in colleges and universities can develop in an all-round way, expand the teaching thinking and teaching methods of young teachers, draw on the advantages of other professions, integrate themselves into the teaching process, and help young teachers to accumulate professional knowledge and diversify teaching style. Taking a building university as an 
example, taking into account the rapid development of knowledge in many aspects such as construction technology, materials and patterns at present, the school encourages teachers to actively participate in domestic academic exchange activities in a policy-oriented manner and regularly organizes university teachers to participate in academic exchanges abroad, in order to broaden the horizons of teachers so that teachers in the classroom teaching can use their own accumulation, in-depth professional knowledge for students.

\subsubsection{To form a diversified teaching model}

With the development of science and technology, information technology is gradually applied to teaching courses, micro-class, flip the classroom into the college campus, the traditional interactive mode has also changed in the classroom. The Internet is widely used in education and teaching, and the interaction between teachers and students formed a new online and offline activities. The traditional teaching by the teachers in the classroom to impart knowledge transfer into the students taking the initiative to search the Internet for teaching resources, in the teaching process teaching focus from the theoretical knowledge transfer into cultivating students practical application to solve the practical problems of students. Under such circumstances, teaching objectives have changed, exercising their ability to learn independently and thinking of innovative ability has become the teaching objectives. Therefore, teachers in the teaching process, we must take a diversified teaching model, scientific and rational use of computer technology and information resources. For example, a college teacher in the teaching process, using micro-class this teaching mode, and allowed students to watch the micro-class to complete the pre-class review work and after-school review work, combined with practical teaching. Taking the logistics management major as an example, the students are organized to simulate the competition, and the content of the class is simulated by means of a scenario, and the teacher judges them.

\subsubsection{Adjust the program of personnel training}

Colleges and universities in carrying out collaborative innovation of production and research work, we must take full account of their own positioning and training characteristics of colleges and universities, the existing personnel training programs and curriculum system optimization, the formation of major and minor, elective system, or cross-disciplinary, cross Curriculum co-cultivation model to help students develop their knowledge. Among them, when formulating talent training programs, teachers should focus on the application of innovative features and the relationship between the structure of professional knowledge and the cultivation of curriculum abilities. In addition, one principle should be followed: "to consolidate the theoretical basis, strengthen practical ability and innovation ability ", on this basis, to adjust the personnel training program [5]. For example, teachers can encourage students to participate in teachers 'research projects, and in the process, guiding students to publish papers, design patents, write research reports and gradually develop students' research and innovation ability. Taking a certain automobile engineering teacher as an example, for four years, Teachers have enabled students to participate in five scientific research projects and dozens of research projects on innovation and entrepreneurship training programs for students, which have fundamentally improved students 'ability of innovation and entrepreneurship, opened up students' thinking horizons and learned more about social needs.

\subsubsection{Improve students' professionalism}

In addition to the above three points, colleges and universities should also increase laboratory construction and improve the practical course system, to ensure that students can better participate in scientific research and technological innovation activities, lay the good foundation for students to start experimental training. Schools in considering their own economic level and strength, if we find their own economic conditions are weak, you can also establish a school-enterprise cooperation, professional internships and internships with business docking, in the enterprise to complete the practice of students and internship process, so that students can better enhance their employability and hands-on ability to enrich the students' future career. Take the logistics industry as an example, 
combining with the trend of professional industry development and professional orientation, we can adopt a variety of ways to build a cooperation model while training creative talents.

\section{Summary}

In conclusion, the new teaching mode of production, studying and research integrates multiple subjects to establish a training mechanism that takes universities and enterprises as the mainstay and the talent market demand as the orientation, and fundamentally it expands the teaching resources. At this stage, all walks of life in our country need compound and applied talents. Therefore, we should make use of this talent cultivation mechanism to start the cooperation between schools and enterprises, change the traditional personnel training mode, and give full play to the role of each subject. In this way, our country's economic development will be fully promoted.

\section{Acknowledgement}

Project: Research Project of Teaching Reform of Higher Education in Jilin Provincial Department of Education.

Project time: The project was established in October 2015.

Project title: Research on Undergraduate College Talent training Mode Based on Collaborative Innovation of Production, Studying and Research.

\section{References}

[1] GAO Junguo, CHI Xiaohong, GUO Ning, et al. Exploration of co-creative talents training mode based on dual mentoring system in colleges and enterprises [C] // An empirical research on improving the quality of higher education.

[2] LI Qihong, SUN Yanchun. Research on Talents Cultivation Model Based on Collaborative Innovation of Production, Teaching and Research in Construction Universities [J]. Industry and Technology Forum, 2017, 16 (13): 250-251.

[3] LI Guoru, WANG Yanzhuo. Research on the Training Mode of Accounting Talents in Transitional Universities - From the Perspective of Collaborative Innovation in Production, Teaching and Research [J]. Silk Road Vision, 2016 (23): 27-29.

[4] CHEN Ting-ting, LI Yunpeng, LIU Yingzhu. Research on Collaborative Innovation of Government, Industry, and Research Based on Talent Cultivation in Universities - A Case Study of Qiqihar Medical College [J]

[5] QI Xin. Analysis of collaborative innovation in production and training of accounting personnel training mode [J]. Silk Road Vision, 2017 (2): 63-63. 